\title{
TWO HUNDRED YEARS OF ENGINEERING GEOLOGY
}

\author{
Martin G. Culshaw ${ }^{1}$, Helen J. Reeves ${ }^{2}$ and Michael S. Rosenbaum ${ }^{3}$ \\ ${ }^{1}$ School of Engineering, University of Birmingham, Edgbaston, Birmingham, B15 2TT, \\ UK (email: martin.culshaw2@ntlworld.com) (formerly British Geological Survey, \\ Keyworth, Nottingham) \\ ${ }^{2}$ British Geological Survey, Keyworth, Nottingham, NG12 5GG, UK \\ ${ }^{3}$ Ludlow, UK
}

On 31 March 2007, a joint meeting of the Engineering Group of the Geological Society and the Yorkshire Geological Society was held as part of the celebration of the bicentenary of the Geological Society of London. The meeting focussed on the lives and achievements of five engineering geologists who have made outstanding contributions to their profession and to science. The meeting formed part of the Society's "Local Heroes" initiative for the bicentenary. The set of papers in this issue of the Quaternary Journal of Engineering Geology and Hydrogeology celebrates the contribution over the last 200 years by scientists and practitioners who have influenced the development of engineering geology or whose work has been particularly important to related aspects of human history. In addition to papers on the individuals discussed at the meeting, additional papers are included that discuss the development of engineering geology, historically and in the context of education and training.

Engineering geology has been an important scientific sub-discipline for as long as people have sought to build and construct their living environment. If nothing else, people soon learnt where buildings could be built safely and where poor foundation conditions or the presence of geohazards meant that unacceptable risks were present. However, engineering geology came to greater prominence with the flowering of geology as a major science in the early $19^{\text {th }}$ century, a time which saw the founding of the Geological Society of London, in 1807.

Of course, there have been many other influential engineering geologists in addition to those discussed in this collection of papers. The emphasis was initially on British contributions in accordance with the thrust of the Local Heroes initiative within the Bicentennial Celebrations of the Geological Society of London (GSL). This formed the basis of a meeting held in Keyworth, Nottingham in 2007 entitled "Engineering Geology through the Centuries" and organised jointly by the Yorkshire Geological Society and the Engineering Group of the GSL. There have, of course, been many contributions from other countries too; the paper by Turner addresses some of these as do accounts such as the one by Kiersch for North America (1991). For the Keyworth meeting, the editors set out to try to cover the whole of the 200 years existence of the Geological Society and chose outstanding individuals whose lives overlapped whilst including links through the cited literature to others whose contributions have been significant. The following were identified, each being selected for a particularly important contribution.

William Smith (1769-1839) can be considered to be the 'Father of Engineering Geology', notwithstanding Kiersch's assertion (1991) that Leonardo da Vinci was the "earliest recorded 'applied geologist' for engineered works". This is not only because 
of Smith's contribution to the development of the modern geological map. He also was involved in a range of engineering work in connection with mines, canals, irrigation and coastal defences. Through this, he realised the significance for safe and efficient construction of understanding the geology, and being able to predict it. He was the first recipient of the Geological Society's premier Wollaston Medal in 1831.

Rudolph Glossop (1902-1993) is most acknowledged for his key role in helping create the British Geotechnical Society (now the British Geotechnical Association) and the Engineering Group of the Geological Society, as well as the scientific journals Géotechnique and the Quarterly Journal of Engineering Geology. Though one of a number of people involved, his leadership role was subsequently recognised by the naming after him of the Geological Society's Glossop Medal, Lecture and Award.

Fred Shotton (1906-1990) was, amongst other accomplishments, a world leading Quaternary geologist and a Fellow of the Royal Society. He has been included because, in addition to his academic research, he provided advice on engineering geological and hydrogeological matters to the military. This led to his involvement in the selection of the landing beaches in Normandy in 1944 and of suitable aeroplane landing strips nearby.

Bill Dearman (1921 to present) was instrumental in developing modern engineering geological mapping methods through the Engineering Group of the Geological Society's Working Party on Engineering Geological Maps and Plans and, with Milan Matula, through the Commission on Engineering Geological Maps of the International Association of Engineering Geology (IAEG). This led to the publication of two guides to engineering geological maps (Anon, 1972; 1976) and a major textbook on the subject (Dearman, 1991). He was awarded the Hans Cloos Medal of the International Association of Engineering Geology in 1990 and the Geological Society's William Smith Medal in 1991.

Peter Fookes (1933 to present) is the fifth distinguished engineering geologist from the United Kingdom to be selected. He is a Fellow of the Royal Academy of Engineering and was awarded the Geological Society's William Smith and Glossop Medals in 1985 and 1997, respectively. In recent years his papers on conceptual engineering geological models are particularly renowned (Fookes, 1997; Fookes et al., 2000) because they set the context for the design and implementation for all site investigations.

It is clear that the meeting failed to produce continuous coverage from William Smith to Peter Fookes but the papers subsequently invited include the contribution by Herbert Lapworth (1875-1933) who would have reduced the gap, and in passing the support instilled by Sir Henry de la Beche (1796-1855) as the first Director of the Geological Survey (1835) and founder of the Royal School of Mines (1851, later to become Imperial College and host to one of the leading schools of engineering geology and geotechnical engineering in the country).

Our choice will be mildly controversial and others would certainly make a different selection. For example, should we have included W J M Rankine, better known for 
his soil mechanics book (Rankine, 1862) but, as Peter Fookes has pointed out, someone who appreciated the importance of geology for engineering (Fookes et al., 2005)? Robert Legget (1904 to 1994) though also an engineer by training and background, fully understood the importance of geology to engineering and published several engineering geology text books such as Geology and Engineering (1939) and Cities and Geology (1973). He was awarded the Geological Society's William Smith Medal in 1977. And if Legget, as an engineer, should be included then Sir Alec Skempton (1914 to 2001) (Lyell Medal winner 1972) ought to be included too! Perhaps Sir John Knill's (1934 to 2002) contribution at Imperial College to modern engineering geology from the 1960s till his untimely death should have been recognised? His 1997 address to the IAEG at Athens and his 2002 Hans Cloos Lecture (following his receipt of the Hans Cloos Medal) showed that right up to the end he had forward-looking ideas about how engineering geology should develop in the broader contexts of society and the environment (Knill, 2001; 2003). Denys Brunsden, was also awarded the William Smith Medal, in 2000, and the Glossop Medal in 2002, was instrumental in having engineering geomorphology accepted as an important part of site investigation. Of the contributions from abroad, few exceed those of Karl Terzaghi, who made a unique contribution to the development of soil mechanics, rock mechanics and engineering geology. Throughout his life there was a fascinating interplay between his contributions to soil mechanics, for which he provided the unifying foundation, and his closely parallel interests in geology and engineering geology (Bjerrum et al., 1960; Goodman, 1999).

However, apart from being historically interesting, does examination of the work of these distinguished engineering geologists help us to understand the important principles that govern research into, and application of, engineering geology? Tepel (2004), in trying to develop an identity for engineering geology, said that "Part of the process must be a serious introspective excursion into the most fundamental aspects of engineering geology, starting with an understanding of its history as a science, a profession, an academic pursuit, and a business pursuit". These papers make a small contribution to Tepel's proposed excursion. What they demonstrate is that having a clear understanding of the three dimensional nature of the ground, its properties and the processes acting upon it, is paramount in ensuring its effective and safe use.

\section{And the future?}

So, armed with some understanding of engineering geology's past development can we look forward and identify future trends that will see the science and its application develop? The Association of Engineering Geologists (AEG) debated the future of engineering geology at four special symposia held over three years at the annual meetings of the AEG in Reno (Nevada) (2002), Vail (Colorado) (2003) and Dearborn (Michigan) (2004) (Anon, 2004). They were particularly concerned with sustainability and stewardship (of engineering geology) (Reno), degree program quality and accreditation (Vail), site characterisation (Dearborn) and understanding conflict and cooperation in the practice of engineering geology. Of particular importance is the last paper of all written by Robert Tepel (2004) in which he attempts to develop a philosophy of engineering geology. The observations below, under the headings 'Training,' 'Practice,' 'Survey,' 'Standards' and 'Research,' attempt to summarise some of the British and American literature, in particular, on the near-future for engineering geology. 


\section{Training}

According to Rogers (2002), the American Engineering Council for Professional Development pushed for the inclusion of engineering geology in undergraduate civil engineering courses from the 1950 s so that by the mid 1970 s nearly $80 \%$ of courses included a compulsory engineering geology module. However, by 2000 this figure had fallen to $6 \%$ with engineering geology modules becoming optional rather than compulsory. This, in part, might be related to the shift from engineering infrastructural development to environmental improvement from the 1970s. Rogers argued that the academic research agenda had shown a similar shift with a consequent fall in the amount of engineering geological research carried out in universities.

In the UK, the situation is similar. The number of universities offering first degrees in geology has roughly halved in the last fifteen years. As a result, the number of engineering geologists in academia would be expected to have declined. Teaching of engineering geology to undergraduates has probably suffered as a result. There are now only four engineering geology postgraduate Masters courses available in the UK - at Imperial College London, Newcastle, Leeds and Portsmouth (and also an undergraduate course at Portsmouth), none with a full-time professor in engineering geology on their staff. Only the latter two are located in 'geology' departments, the others being hosted by engineering faculties. This state of affairs threatens the adequate supply of suitably trained engineering geologists for both research and practice.

\section{Practice}

In looking to the future of geotechnical practice, Rogers (2002) made a number of other observations:

- that engineering decisions were being made on decreasing amounts of sitespecific information. This probably reflects current reality but challenges the arguments of Culshaw (2005) who suggested that the increasing availability of attributed three dimensional engineering geological models had the potential to revolutionise site investigation;

- that site characterisation costs will continue to fall. Market forces undoubtedly continue to push in this direction but would a number of high profile failures of structures caused by 'unforeseen ground conditions' change this?

- that "engineering geologists will need to re-invent themselves" using new techniques and technology. Engineering geologists have been particularly good at this. However, improved technology for the remote sensing of the ground, whether from the surface, or from the air or from space, and rapidly developing software for computer 3D modelling and visualisation, will provide new models of much higher quality than in the past. Engineering geologists will need to know when to commission such surveys and how to interpret the results from them;

- that engineering geologists should not "sacrifice quality for cost." Most engineering geologists would agree with this statement, but are they in a position to enforce it?

Anecdotal evidence suggests that engineering geological practice in the UK is relatively healthy at the present time, with the biggest threat being the continued supply of adequately trained engineering geologists, particularly at Masters level. The 
increase in the number of four year undergraduate courses with a broad, and not necessarily applied, curriculum, but leading to a MSci degree, places specialist Masters (MSc) courses under threat because of the difficulty of persuading the best students to fund a fifth year of study at a time when the Natural Environment Research Council (NERC) is increasingly reluctant to fund MSc studentships.

\section{Survey}

Like most geological surveys, it is the responsibility of the British Geological Survey (BGS) to maintain and develop the nation's understanding of its geology to improve policymaking, enhance national wealth and reduce risk. The BGS programme seeks to supply relevant geological information to enable local, regional and national government, government agencies (such as the Environment Agency) and other public and private sector organizations, to make evidence-based decisions. It also carries out research directed towards implementing the science strategy of its parent body, NERC (Anon, 2007a). The principle science themes include the climate system, the sustainable use of resources, natural hazards and environment, pollution and human health, which the Survey attempts to address through enhancement of its national, strategic and long term databases, specialist applied research studies and collaborative work with academia and the private and public sectors. However, in the BGS's own new strategy (2007), the carefully established balance between a) information collection, validation and management (Culshaw et al., 2006), b) applied research, both funded through the civil science budget (SB), and c) commissioned research and commercial activity, funded by stakeholders and clients, is being reconsidered. The engineering geological and geotechnical community will want reassurance that national information holdings, whether as point data, 2D maps or 3 or 4D models, will be maintained and enhanced in the future and that applied research (rather than pure or orientated basic research) will remain a key aspect of what the BGS does.

Geological knowledge is the essential foundation for the diverse range of services that BGS now provides to fulfil its remit as the national geological survey. Industry also needs similar information to underpin site investigation and the production of environmental impact assessments. This geoscience knowledge base may include up-to-date information on artificial (anthropogenic) deposits, superficial deposits and bedrock geology. From these, various derived thematic layers can be compiled, for example relating to contaminated land, engineering properties, landslide susceptibility, flood plain limits and baseline environmental geochemistry.

Engineering geological work continues to be funded, mainly under the heading 'Land Use and Development.' Perhaps the most important long-term programme is the Engineering Geology of UK Rocks and Soils Project, characterising UK geological formations in terms of their lithological and engineering properties. These properties can provide information on potential engineering behaviour, such as problem ground conditions and geological hazards. This information may be used to assist ground engineers and planners in undertaking feasibility studies and site investigation design for engineering projects and land-use planning for regional development. Studies on the Gault (Forster, et al., 1994) and the Mercia Mudstone (Hobbs et al., 2002) are published and ones on the Lambeth Group (Entwisle et al., 2008) and the Lias Group (Hobbs et al., 2008) are in press. A study of Quaternary Brickearth is nearing completion. This is being reported in a series of papers in the literature (for example, 
Northmore et al., 1996, Jefferson et al., 2001, Clarke et al., 2007, Milodowski et al., 2008). A study on Glacial Tills is underway. All geotechnical data from these studies are stored in the National Geotechnical Properties Database (Self \& Entwisle, 2006), which contains geotechnical data from tens of thousands of boreholes. Other relevant databases include digital 2D geological maps at 1:10 000, 1:50 000 and 1:250 000 scale (Jackson \& Green, 2003), 3D geological models (Culshaw, 2005), the National Landslide Database (Gibson et al., 2005) and the National Karst Database (Cooper et al., 2001)

\section{Standards}

From the point of view of information, the future is about its provision in digital form in a standard format. The Association of Geotechnical and Geoenvironmental Specialists is internationalising its initiative to create a universal data transfer format (DIGGS - Data Interchange for Geotechnical and Geoenvironmental Specialists) (Anon, 2007b). This, together with the newly formalised international standards for the description and classification of soils and rocks (Anon, 2003a, b, c) is bringing the methods and practice adopted by engineering geologists closer to a consistent international standard (Norbury, 2004). This is most significant and, perhaps, represents the final step in a process that has lasted more than 50 years. We can now see a time when engineering geologists around the world will speak the same language when describing and classifying soil and rock materials and masses.

\section{Research}

Hatheway et al. (2004) highlighted the effects of the UK's Research Assessment Exercise and its use of citation indices on the development of engineering geology within academe. The problem seems to be that in our university culture, the publication of research papers in peer-reviewed journals with high impact factors in the Science Citation Index is all that matters. However, all engineering geological and geotechnical journals have low impact factors (largely because the number of people in the disciplines is comparatively small and so papers are cited less often). In some universities, staff are advised not to publish in journals with an impact factor of less than 1! As a result, engineering geology (and geotechnical engineering) is not necessarily regarded highly by university managers. Because of this artificially created low rating, the subject has a low status and so our Research Councils and other funding agencies are less inclined to fund research in these fields. The Editorial Board of the Quarterly Journal of Engineering Geology and Hydrogeology has looked into this and agrees that the methodology used by the compilers of the Science Citation Index is flawed when it comes to applied sciences. Changing things is quite another matter. However, the result is that less engineering geological research is funded and fewer doctorate students graduate. Masters courses (referred to above) are continually under threat because staff do not generate enough research (because of lack of funding) and, economically, the courses are judged to be only marginally viable, at best.

In terms of what research needs to be done, Griffiths and Culshaw (2004) described opportunities for research in the six main component areas of engineering geology:

- ground materials and structures

- regional characteristics

- surface processes and materials

- ground investigations 
- material properties

- difficult ground conditions

However, the key issue is not what research needs doing but how it will be funded, given that both the relevant UK Research Councils (NERC and EPSRC, the Engineering and Physical Sciences Research Council) seem increasingly reluctant to fund engineering geological research, partly because it is perceived that this area of science falls between the two Research Councils).

\section{Conclusions}

Engineering geology in the UK has a very long and honourable history. It has produced a succession of internationally-renowned academics and practitioners whose achievements are highlighted in the companion papers in this issue. It has led the development of international standards for description and classification. It has contributed significantly to research into the properties and behaviour of rocks and soils, the creation and visualisation of 3D models of the shallow subsurface, and the understanding of geohazard processes and their mitigation. As long as there is a steady supply of well-trained graduates to apply the developing international standards and the research outputs, it would seem that the health of engineering geology is reasonably good. However, the state of engineering geological research remains a concern as funding is hard to come by from academic sources and many companies are unable, or unwilling, to contribute very much. Furthermore, if research is seen to falter, the very future of the British university as a base for the subject is thrown into doubt, raising concern as to how future generations of engineering geologists are to be educated and trained and whether engineering geology, as a distinct, professional, sub-discipline of geology, will continue to exist at all.

Acknowledgements: This paper is published with the permission of the Executive Director of the British Geological Survey (NERC).

\section{References}

Anon, 1972. The preparation of maps and plans in terms of engineering geology. Quarterly Journal of Engineering Geology, 3, 1-24.

Anon, 1976. Engineering geological maps. A guide to their preparation. The UNESCO Press, Paris. 79p.

Anon, 2003a. Geotechnical engineering - identification and classification of soil -

Part 1, Identification and description. EN $14688-1$. ISO/TC 182/SC 1.

Anon, 2003b. Geotechnical engineering - identification and classification of soil Part 2, Classification. EN 14688 - 2. ISO/TC 182/SC 1.

Anon, 2003c. Geotechnical engineering - identification and classification of rock. EN 14689. ISO/TC 182/SC 1.

Anon, 2004. Visioning the future of engineering geology. Special Publication No. 19, Association of Engineering Geology, Denver, Colorado. On CD-ROM.

Anon, 2007a. Next generation science for planet Earth. NERC strategy 2007-12. Natural Environment Research Council, Swindon. 32p.

Anon, 2007b. DIGGS ploughs on in quest for improved data handling. AGS News No. 55, 1.

Bjerrum, L., Casagrande, A., Peck, R.B. \& Skempton, A.W., 1960. From theory to practice in Soil Mechanics. John Wiley, $424 \mathrm{p}$. 
Clarke, M., Milodowski, A.E, Bouch, J., Leng, M.J. \& Northmore, K.J., 2007. New OSL dating of UK loess: indications of two phases of Late Glacial dust accretion in SE England and climate implications. Journal of Quaternary Science, 22, 361 171.

Cooper, A.H., Farrant, A.R., Adlam, K.A.M. \& Walsby, J.C., 2001. The development of a national geographic information system (GIS) for British karst geohazards and risk assessment. In Beck, B.F. and Herring. J.G. (eds.) Geotechnical and environmental applications of karst geology and hydrogeology. Proceedings of the Eighth Multidisciplinary Conference on Sinkholes and the Engineering and Environmental Impacts of Karst, April 1-4 $4^{\text {th }}$ Louisville, Kentucky, USA. Balkema Publishers. 125-130.

Culshaw, M.G., 2005. From concept towards reality: developing the attributed 3D geological model of the shallow subsurface. Quarterly Journal of Engineering Geology and Hydrogeology, 38, 231-284.

Culshaw, M.G., Jackson, I. \& Giles, J.R.A., 2006. The provision of digital spatial data for engineering geologists. Bulletin of Engineering Geology and the Environment, $65,185-194$.

Dearman, W.R., 1991. Engineering geological mapping. Butterworth-Heinemann Ltd., Oxford. 387p.

Entwisle, D.C., Hobbs, P.R.N., Northmore, K.J., Jones, L.D., Ellison, R.A., Cripps, A.C., Skipper, J., Self, S.J., \& Meakin, J.L., 2008. Engineering geology of UK rocks and soils: Lambeth Group. British Geological Survey Report. In press.

Fookes, P.G., 1997. The First Glossop Lecture: Geology for engineers: the geological model, prediction and performance. Quarterly Journal of Engineering Geology, 30, 290-424.

Fookes, P.G., Baynes, F.J. \& Hutchinson, J.N., 2000. Keynote Lecture: Total geological history: a model approach to the anticipation, observation and understanding of site conditions. In: Proceedings of an International Conference on Geotechnical and Geological Engineering (GeoEng 2000), Melbourne, 1, 370460.

Fookes, P.G., de Freitas, M.H. \& Culshaw, M.G., 2005. Discussion of 'The first engineering geological publication in the UK?' by M.G. Culshaw Quaternary Journal of Engineering Geology and Hydrogeology, 37, 227-231. Quaternary Journal of Engineering Geology and Hydrogeology, 38, 105-108.

Forster, A., Hobbs, P.R.N., Cripps, A.C., Entwisle, D.C., Fenwick, S.M.M., Raines, M.R., Hallam, J.R., Jones, L.D., Self, S.J. \& Meakin, J.L., 1994. Engineering geology of British rocks and soils: Gault Clay. British Geological Survey Technical Report, WN/94/31. 60p.

Gibson, A.D., Forster, A., Culshaw, M.G., Cooper, A.H., Farrant, A., Jackson, N. \& Willet, D., 2005. Rapid geohazard assessment system for the UK natural gas pipeline network. In: "Geology and Linear Infrastructures," Proceedings of an International Symposium (GEOLINE), Lyon, France, 23-25 May 2005. Orléans: BRGM Éditions. ISBN 2-7159-2982-X. (On CD-ROM).

Goodman, R.E., 1999. Karl Terzaghi. The Engineer as an Artist. American Society of Civil Engineers, 340p.

Griffiths, J.S. \& Culshaw, M.G., 2004. Seeking the research frontiers for UK engineering geology. Quarterly Journal of Engineering Geology and Hydrogeology, 37, 317-325.

Hatheway, A.W., Kanaori, Y., Cheema, T., Griffiths, J. \& Promma, K., 2004. $9^{\text {th }}$ Annual Report of the Status of Engineering Geology - Year 2003-4. 
Encompassing hydrogeology, environmental geology and the applied geosciences. Engineering Geology, 74, 1-31.

Hobbs, P.R.N., Hallam, J.R., Forster, A., Entwisle, D.C., Jones, L.D., Cripps, A.C., Northmore, K.J., Self, S.J. \& Meakin, J.L., 2002. Engineering geology of British rocks and soils: mudstones of the Mercia Mudstone Group. British Geological Survey Research Report, RR/01/02. 106p.

Hobbs, P.R.N., Entwisle, D.C., Northmore, K.J., Sumbler, M.G., Jones, L.D., Kemp, S., Self, S.J., Barron, M. \& Meakin, J.L., 2008. Engineering geology of British rocks and soils: Lias Group. British Geological Survey Report. In press.

Jackson, I. \& Green, C., 2003. DigMapGB - the digital geological map of Great Britain. Geoscientist, 13, 2, 4-7.

Jefferson I., Northmore K.J. \& Tye, C., 2001. Behaviour of silt: The engineering characteristics of loess in the UK. In: Jefferson, I., Murray, E.J. Faragher, E, \& Fleming, P.R. (eds). Problematic Soils Proceedings of an East Midlands Geotechnical Group / Institution of Civil Engineers Symposium, Nottingham Trent University, November 2001. Chapter 2, 37-52.

Kiersch, G.A. (ed.), 1991. The heritage of Engineering Geology: the First Hundred Years. Geological Society of America, Centennial Special, 3, 605p.

Knill, J.L., 2001. Environmental change and engineering geology: our global challenge. Engineering Geology and the Environment. Balkema, 4, 3355-3361.

Knill, J.L., 2003. Core values: the first Hans Cloos Lecture. Bulletin of Engineering Geology and the Environment, 62, 1-34.

Legget, R.F., 1939. Geology and engineering. McGraw-Hill Book Company Inc., New York, 650p.

Legget, R.F., 1973. Cities and geology. McGraw-Hill Inc., New York, 624p.

Milodowski, A.E., Northmore, K.J., Kemp, S.J., McKervey, J.A., Entwistle, D.C., Bouch, J.E., Gunn, D.A., Jackson, P.D., Boardman, D.I., Zoumpakis, A., Rogers, C.D.F., Dixon, N., Jefferson, I., Smalley, I.J. \& Clarke, M., 2008. The mineralogy and fabric of 'Brickearths' and their relationship to engineering behaviour. Engineering Geology. (In Press)

Norbury, D., 2004. Current issues relating to the professional practice of engineering geology in Europe. In: Hack, R., Azzam, R. \& Charleir, R. (eds), Proceedings of the $1^{\text {st }}$ European Regional IAEG Conference on Engineering Geology for Infrastructure Planning in Europe: a European Perspective. Springer-Verlag, Berlin, 15-30.

Northmore, K.J., Bell, F.G. \& Culshaw, M.G., 1996. The engineering properties and behaviour of the Brickearth of South Essex. Quarterly Journal of Engineering Geology, 29, 147-161

Rankine, W.J.M., 1862. A manual of civil engineering. Griffith and Bohn, London.

Rogers, J.D., 2002. Disappearing practice opportunities: why are owners and engineers taking increased risks? What can be done to counter this threat? In: Proceedings of a Symposium "Visioning the future of engineering geology: stewardship and sustainability," 26 September 2002, Reno, Nevada at the Joint Annual Meeting of the Association of Engineering Geologists (AEG) and the American Institute of Professional Geologists (AIPG). Special Publication 14 (on CD-ROM). Association of Engineering Geologists, Denver, Colorado, 14p. A pdf version of the presentation of this paper entitled: "A brief overview of geological engineering and where the profession is headed" is available on the website: http:///web.umr.edu/ rogersda/umrcourses/ge341/Disappearing\%20Practice\%20 Opportunities.pdf 
Self, S.J. \& Entwisle, D.C., 2006. The structure and operation of the BGS National Geotechnical Properties Database. British Geological Survey Internal Report IR/06/092.

Tepel, R.E.M., 2004. Toward a philosophy of engineering geology. In: Proceedings of a Symposium "Visioning the future of engineering geology: understanding conflict and cooperation in the practice of engineering geology", $1^{\text {st }}$ October 2004, Dearborn, Michigan at the $47^{\text {th }}$ Annual Meeting of the Association of Engineering Geologists (AEG). Special Publication 19. Association of Engineering Geologists, Denver, Colorado, 44p. 